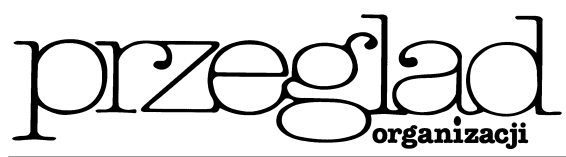

\title{
Monitorowanie skuteczności systemu zarządzania jakością ISO 9001:2000 w świetle wymagań dotyczących zarządzania procesowego
}

https://doi.org/10.33141/po.2005.05.11

Jacek Łuczak

\section{Wprowadzenie}

W spółczesne koncepcje zarządzania, z uwagi na wymagania rynkowe oraz charakterystykę zachowań uczestników rynku, z założenia muszą odwoływać się do rozwiązań gwarantujących skuteczność. W historii przełomowe okazały się koncepcje kierowania opracowane i rozwijane przez Adama Smitha, Henry'ego Forda, czy Alfreda Sloana ${ }^{1)}$ Przy tym jednak ich style kierowania rozwinięte zostały w postaci organizacji zarządzanych funkcjonalnie. Współcześnie Hammer i Champy ${ }^{2}$ oraz inni autorzy $^{3)}$ motywują do myślenia procesowego, co ich zdaniem jest najbardziej skuteczną formą rozwinięcia logiki funkcjonowania przedsiębiorstwa. Dla potwierdzenia powyższej hipotezy należy zwrócić uwagę na wymagania międzynarodowej normy ISO 9001:2000, która wprowadziła istotne zmiany w rozumieniu systemu zarządzania jakościa, począwszy od jego planowania, poprzez monitorowanie i kontrolę, a kończąc na doskonaleniu.

Zgodnie z wymaganiami niniejszej normy, system zarządzania jakością ma spełnić wymaganie skuteczności. Jest to jedno z podstawowych założeń obok konieczności ustanowienia, wdrożenia i ciągłego rozwoju systemu ${ }^{4)}$.

Zapewnienia skuteczności ustanowionego systemu zarządzania należy związać z innymi wymaganiami normy ISO 9001:2000, w szczególności z planowaniem jakości oraz zarządzaniem procesowym ${ }^{5}$, podobnie z ciągłym doskonaleniem, monitorowaniem wyrobu i procesów, działaniami korygującymi i innymi. Celem niniejszego artykułu jest zaprezentowanie koncepcji monitorowania skuteczności systemu zarządzania jakością opartej na podejściu procesowym. Przy czym założeniem autora jest uniwersalność proponowanych rozwiązań i możliwość zastosowania niezależnie od koncepcji zarządzania danej organizacji ${ }^{6}$.

\section{Procesowe zarządzanie jakością w świetle norm ISO serii 9001:2000}

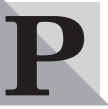

odejście procesowe jest jedną z podstawowych zasad systemowego zarządzania jakością, zgodnego z wymaganiami ISO 9001:2000.
Przegląd Organizacji, Nr 5 (784), 2005, ss. 40-43 www.przegladorganizacji.pl Towarzystwo Naukowe Organizacji i Kierownictwa (TNOiK)

Praktyka dowodzi, że często podejmowane działania, chociaż akceptowane przez jednostki certyfikujące ${ }^{7)}$ sa zaledwie namiastką rozwiązań określonych w teorii zarządzania procesami biznesowymi ${ }^{8)}$.

Chociaż do lamusa odeszła koncepcja zarządzania jakością ogniskowana wokół spełniania wymagań standardu - określonego w poszczególnych punktach normy. Obecnie nadrzędna myśl systemu to zarządzanie organizacją przez pryzmat procesów ukierunkowanych na kreowanie wartości dodanej dla klientów, a zatem synergia wiedzy z różnych dziedzin oraz pracy wykonywanej równolegle w całej firmie i jej otoczeniu (kooperanci, klienci, konkurencja).

\section{Skuteczność procesowego systemu zarządzania jakością}

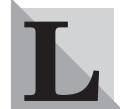

iteratura przedmiotu obszernie wyjaśnia pojęcie skuteczności, niejednokrotnie odmiennie, nieraz nawet sprzecznie wobec różnych koncepcji zarządzania. Skuteczność to stopień, w jakim planowane wyniki zostały osiagnięte ${ }^{9)}$. Skuteczny system zarządzania to taki, który pozwala na osiąganie planowanych w jego ramach celów i stawianych zadań $^{10)}$. Skuteczność może dotyczyć tak zarządzania projektem - czyli wdrażania ${ }^{11}$ systemu zarządzania, jak również jego utrzymania i rozwoju. Zarówno w pierwszym, jak i drugim przypadku pomiar skuteczności wymaga wypracowania określonej koncepcji.

Norma ISO 9001:2000 określa wymagania dotyczace stawiania celów jakościowych. Powinny być mierzalne i spójne z polityką jakości organizacji. W praktyce konieczne jest formalne, udokumentowane wskazanie celów, definiowanie sposobu ich pomiaru, identyfikacja niezbędnych zasobów i czasu do ich osiagnnięcia. Cele mogą być uszczegóławiane przez zadania.

\section{Identyfikacja procesów}

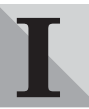

dentyfikacja procesów (mapowanie procesów), czyli wybór kluczowych procesów w firmie stanowi pierwszy etap procesowego zarządzania jakością. W konsekwencji powstaje tzw. model kontekstowy. Zważywszy na fakt, że w dalszej kolejności zachodzi konieczność pokazania korelacji 
pomiędzy procesami, najczęściej zakłada się ich przynależność do dwóch lub większej liczby grup. Najpowszechniejszy jest jednak model dwóch grup procesów. Procesy są wyodrębniane ze względu na role, jakie pełnią w organizacji i wzajemne powiązania, a więc:

- procesy podstawowe, w efekcie których powstaje wyrób lub usługa związana pośrednio lub bezpośrednia z działalnością firmy. Na ogół procesy te tworza wartość dodaną w tzw. łańcuchu wartości dodanej. Do procesów tych można zaliczyć: badania rynku, projektowanie produktu, dostarczanie produktu, sprzedaż, marketing, obsługę klienta;

- procesy wspierające, które służą do zapewnienia sprawnego funkcjonowania firmy i umożliwiają realizację procesów podstawowych. Nie tworzą więc bezpośrednio wartości dodanej dla klienta. Do procesów tych można zaliczyć: planowanie strategiczne, zarządzanie zasobami ludzkimi, finanse-księgowość, obsługę informatyczną i logistyczną itp.

Mapa procesów w każdym przypadku powinna łączyć w sobie zarówno wiedzę związaną z mapowaniem procesów, jak również uwzględniać specyfikę samej organizacji. Rysunek prezentuje fragment przykładowej mapy procesów dużego przedsiębiorstwa produkcyjnego.

Identyfikacja kluczowych procesów stanowi podstawę do opracowania architektury procesów wcho- dzących w skład systemu zarządzania. Architektura procesów jest niczym innym, jak uporządkowanym obrazem struktury procesów ze względu na skalę działania w organizacji. Z punktu widzenia stosowania narzędzi informatycznych może ona obejmować:

- procesy międzyobszarowe (tzw. megaprocesy),

- procesy obszarowe (tzw. procesy główne),

- procesy elementarne (tzw. czynności indywidualne).

Budowa architektury procesów polega zatem na stopniowym uszczegóławianiu poszczególnych kluczowych procesów gospodarczych na coraz bardziej elementarne składniki. Z punktu widzenia odpowiedzialności wiodącą rolę odgrywają tzw. właściciele procesów. Ich rola polega z jednej strony na operacyjnym koordynowaniu przepływu działań w ramach procesów, z drugiej zaś - na zarządzaniu procesami, a więc wyznaczaniu celów i mierników, analizie oraz doskonaleniu (podejmowaniu i weryfikacji działań korygujących i zapobiegawczych).

\section{Modelowanie i dokumentacja procesów}

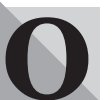
czekiwanym rezultatem identyfikacji procesów są ogólne i szczegółowe mapy procesów (diagramy). Kolejnym istotnym elementem wdrażania procesowego zarządzania jakością jest za-

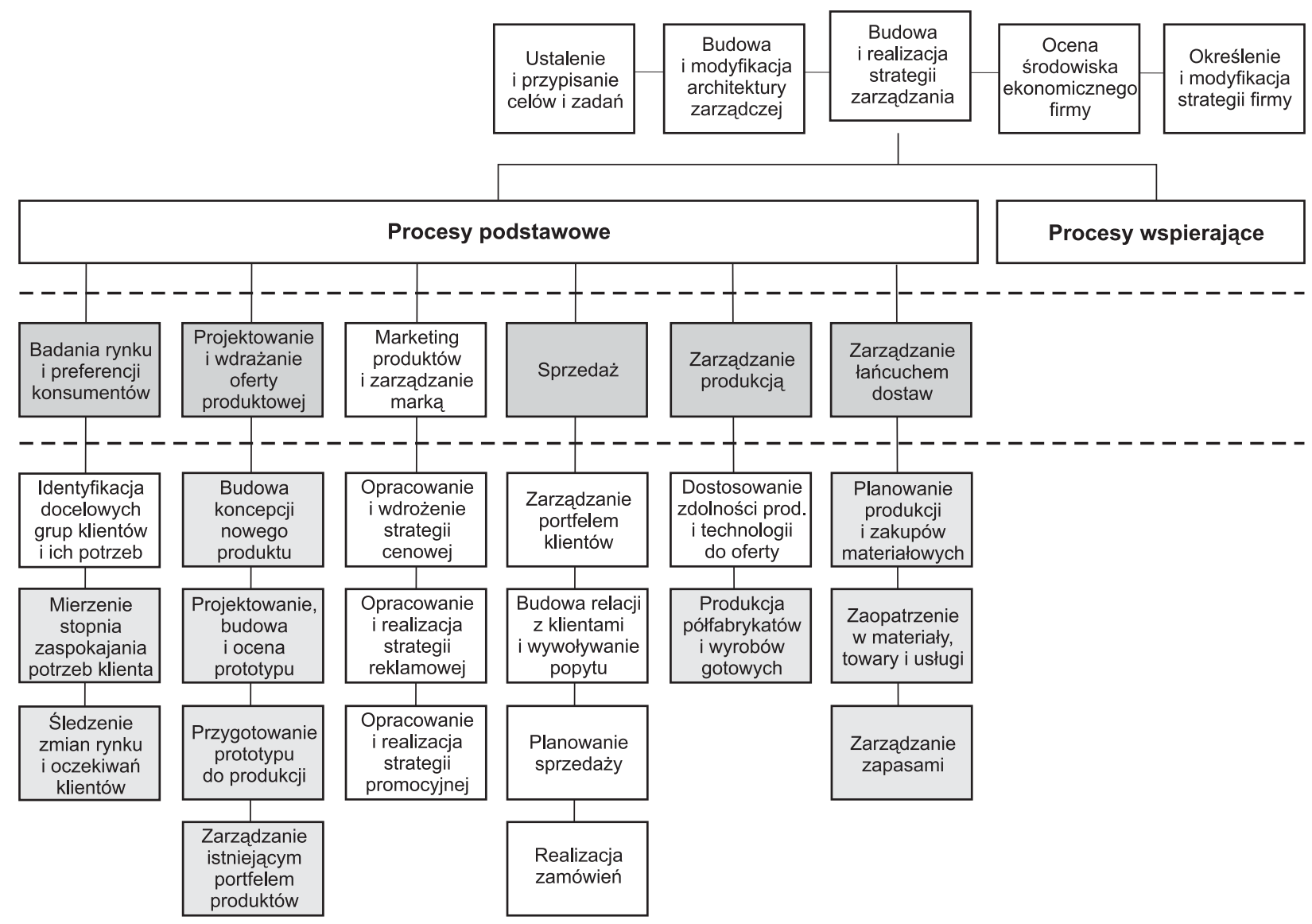

Rys. Przykładowa mapa procesów $\mathrm{w}$ dużym przedsiębiorstwie produkcyjnym - procesy podstawowe $^{12)}$

Źródło: opracowanie własne, w ramach projektu reorganizacji procesów biznesowych w przedsiębiorstwie produkcyjnym, $2003 \mathrm{r}$. 
tem tworzenie map, ukazujacych przebieg i wzajemne oddziaływanie procesów. Tak graficznie przedstawione procesy umożliwiają weryfikację, jak dalece podejmowane działania ukierunkowane są na wewnętrznego lub zewnętrznego klienta oraz przyczyniają się do tworzenia wartości dodanej dla organizacji.

Opisane procesy obejmują określoną sekwencję czynności, które pozostaja w bezpośredniej zależności (realizacja jednej umożliwia przejście do kolejnej). Tak więc, istotnym elementem opisu procesu powinny być:

- kolejno realizowane funkcje,

- odpowiedzialność za realizację poszczególnych funkcji (stanowisko, itp.),

- dokumenty na „wejściu” i „wyjściu”.

Dokumentacja przygotowywana $\mathrm{w}$ ramach systemu zarządzania jakością powinna być zorientowana procesowo, co sprzyja lepszemu odbiorowi zadań przypisanych pracownikom.

Współczesne systemy zarządzania jakością wymagają dokumentacji adekwatnej do rozumienia i wykorzystywania teorii zarządzania procesowego, dlatego opracowywane sa niejednokrotnie wcześniej nie spotykane dokumenty, np. karty procesów, czy księgi procesów, które pełnią wręcz wiodącą rolę w identyfikacji metod i kryteriów wykonywania procesów.

Karta procesu może być dokumentem wiodaccym, opracowana dla każdego procesu z mapy może bowiem zawierać zarówno dane charakteryzujące dany proces, jak również związane z jego planowaniem, monitorowaniem i rozwojem. Na przykład wobec każdego procesu stawiane mogą być trzy rodzaje celów:

- podstawowe - definiowane jako działanie celowe (np. dla procesu zarządzanie kadrami: zapewnienie kompetentnego personelu do realizacji zadań zawodowych w organizacji);

- monitorujące - definiowane jako wskaźniki, których wartości powinny być odczytywane jako ewentualne sygnały wczesnego ostrzegania (np. dla procesu zarządzanie kadrami: absencja pracowników produkcyjnych powyżej $2 \%$ );

- doskonalące - definiowane jako cele, których osiagnięcie uznane będzie jako prawidłowy kierunek modelowania i rozwoju procesu (np. dla procesu zarządzania kadrami: zmniejszenie rotacji pracowników na stanowiskach kierowniczych w okresie 1 roku po rekrutacji do zera).

Norma ISO 9001:2000 stawia wymagania wobec dokumentacji systemu zarządzania jakością, w szczególności odwołuje się do konieczności opracowania udokumentowanych procedur ${ }^{13)}$. Przy czym intencja wymagań jest indywidualizacja dokumentacji systemowej, z uwagi na kompetencje personelu, złożoność procesów i specyfikę organizacji. Wreszcie procedura definiowana jest jako ustalony sposób przeprowadzenia działania lub procesu ${ }^{14)}$. Wobec powyższego może przybierać dowolne postacie i formy prezentacji.

\section{Parametryzacja procesów}

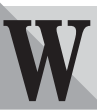
ażną cechą systemów zarządzania jakością zgodnych z ISO 9001:2000 oraz podejścia procesowego jest pomiar skuteczności, a przez to konieczność parametryzacji procesów. Wiąże się to w praktyce z koniecznością określenia ${ }^{15)}$ :

- głównych celów jakościowych,

- wynikowych i wiodących mierników,

- docelowych wartości mierników.

Parametryzacja powinna być prowadzona dla poszczególnych procesów w ramach opracowanej mapy procesów. W praktyce systemowego zarządzania jakością określane są zatem cele, mierniki i ich wartości docelowe, przynajmniej dla tzw. megaprocesów. W dalszej kolejności natomiast określane są cele, mierniki i wartości docelowe dla procesów głównych (obszarowych niższego poziomu). Ostatecznie są one przekładane na poziom najniższy - operacyjny. W konsekwencji każdy pracownik ma świadomość postawionych przed nim celów i zadań w ramach danego procesu.

\section{Zakończenie - doskonalenie procesów}

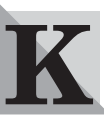
onieczne jest wprowadzenie zasady $\mathrm{PDCA}^{16)}$, zarówno w odniesieniu do pojedynczego procesu, jak i struktury procesów zgodnie z modelem graficznym proponowanym w normach ISO 9001:2000.

Doskonalenie procesu realizuje się w wyniku przeprowadzenia analizy danych z procesu oraz kreowania celów i podejmowania działań poprawiających sprawność procesu. Efektem doskonalenia procesu może być zarówno poprawa jakości wyrobu powstającego w procesie, jak i obniżka kosztów prowadzenia procesu. Można przyjąć, że wyrób jest na tyle dobry, na ile dobry jest proces, w którym ten wyrób powstał.

Do prowadzenia kompleksowej oceny mierników procesów można wykorzystać Zrównoważoną Kartę Wyników ${ }^{17)}$ (The Balanced Scorecard). Pozwala ona uchwycić zależności pomiędzy poszczególnymi sfera-

Tab. Zestawienie celów ${ }^{18)}$ dla procesu: produkcja $\mathbf{w}$ przedsiębiorstwie produkującym autobusy oraz pojazdy specjalne

\begin{tabular}{|c|c|c|}
\hline Lp. & Nazwa wskaźnika & Kryteria oceny \\
\hline 1. & $\begin{array}{c}\text { Stopień realizacji miesięcznego harmonogramu } \\
\text { produkcji w zakładzie w Z2 }\end{array}$ & $\begin{array}{c}\text { Liczba przekazanych autobusów } \times 100 \% / \text { Liczba } \\
\text { autobusów zaplanowanych }\end{array}$ \\
\hline 2. & $\begin{array}{c}\text { Stopień realizacji miesięcznego harmonogramu } \\
\text { produkcji w zakładzie w Z1 }\end{array}$ & $\begin{array}{c}\text { Z1 przekazanych autobusów } \times 100 \% / \text { Z2 autobusów } \\
\text { zaplanowanych }\end{array}$ \\
\hline 3. & Pracochłonność dla standardowego autobusu U12 & Liczba roboczogodzin wynikających z kart pracy \\
\hline 4. & Pracochłonność dla standardowego autobusu U15 & Liczba roboczogodzin wynikających z kart pracy \\
\hline
\end{tabular}

* Z1, Z2 to oznaczenie pierwszego i drugiego zakładu produkcyjnego. 
mi funkcjonowania organizacji: finansami, klientami, procesami i zasobami, a zwłaszcza określić wpływ procesów na dwa pierwsze obszary. Podobnie użyteczna może być japońska metoda Hoshin ${ }^{19)}$, związana z budową strategii zarządzania.

Zapewnienie sprawnego zbierania i analizowania danych jest możliwe tylko w przypadku zapewnienia wsparcia informatycznego zarządzania procesów. Wręcz zdaniem niektórych autorów, jest ono warunkiem profesjonalnego zarządzania procesowego ${ }^{20)}$.

Opracowane w ramach poprzednich etapów prac modele procesów biznesowych wraz z systemem pomiaru stanowią podstawę do podjęcia działań optymalizacyjnych. W ramach doskonalenia procesów stosować można generalnie dwie metody ${ }^{21)}$ :

- usprawnianie procesów,

- reorganizacje procesów (reengineering).

Usprawnianie procesów prowadzi do modyfikacji stanu istniejącego, w wyniku której zwiększa się efektywność i wydajność procesu. Usprawnienie stosowane jest do racjonalizacji procesu w małym obszarze jego funkcjonowania lub zmiany tylko wybranych elementów procesu.

Reorganizacja procesów prowadzi do radykalnej zmiany w realizacji procesu i co za tym idzie jego efektywności. Reorganizacja ma zatem szerszy charakter i często związana jest z projektowaniem przebiegu procesu od początku na podstawie przyjętych założeń i wymagań klienta. W myśl wiodacej definicji reengineering $^{22)}$ to fundamentalne przemyślenie od nowa i radykalne przeprojektowanie procesów w firmie, prowadzące do przełomowej poprawy - według krytycznych, współczesnych miar osiąganych wyników, takich jak: koszt, serwis, szybkość.

Procesowe zarządzanie jakościa wyznacza nowe podejście do systemowego zarządzania jakością. W pełnym zakresie odpowiada koncepcji kompleksowego zarządzania jakością (Total Quality Management). Stałe doskonalenia procesów, w które włączona jest kadra zarządzająca, kierownictwo oraz wszyscy pracownicy na poszczególnych szczeblach procesowej orientacji firmy prowadzi do ciągłej poprawy jakości oferowanych usług lub produktów. W konsekwencji pozwala na korelację dbałości o jakość i zadowolenie klienta oraz pragmatycznego podejścia do prowadzenia działalności gospodarczej.

dr Jacek Łuczak

Katedra Ekonomiki Jakości Akademia Ekonomiczna w Poznaniu

\section{PRZYPISY}

1) Zob. m.in. A. SMITH, Badania nad natura i przyczynami bogactwa narodów, PWN, Warszawa 1954; A. LIEBFELD, Henry Ford. Legenda i rzeczywistość, KiW, Warszawa 1970; A.P. SLOAN, Jr., Moje lata $z$ GM, WNT, Warszawa 1993; S.P. ROBBINS, D.A. DeCENZO, Podstawy zarzadzania, PWE, Warszawa 2002, s. 59.

2) Zob. M. HAMMER, J. CHAMPY, Reengineering $w$ przedsiębiorstwie, Neuman Management Institute, Warszawa 1996, s. 25; M. HAMMER, Reinżynieria i jej następstwa, PWN, Warszawa, 1999, s. 81.

3) Zob. m.in. R.L. MANGANELLI, M.M. KLEIN, Reengineering, PWE, Warszawa 1998, s. 27.

4) Patrz PN-EN ISO 9001:2000, System zarzadzania jakościq. Wymagania, p. 4.1, s. 21.
5) Tamże.

6) Zdaniem twórców teorii Business Process Reengineering, koncepcja zarządzania procesowego stoi w sprzeczności $\mathrm{z}$ dominujacymi w organizacjach funkcjonalnymi zasadami zarządzania, charakteryzującymi się $\mathrm{m}$. in. jednoosobowym kierownictwem, hierarchizacją odpowiedzialności, kompetencji i komunikacji. Więcej na temat systemów zarzadzania m.in. M. HAMMER, J. CHAMPY, Reengineering in Corporation. A Manifesto for Business Revolution, HarperBusiness 1993; N. GAITHER, Production and Operations Management, ITP, s. 196.

7) Zob. J. ŁUCZAK (red.), Jakość ustug certyfikacyjnych systemów zarzadzania, Oficyna Współczesna, Poznań 2004.

8) M.in. R. MANGANELLI, M. KLEIN, Reeingineering, PWE, Warszawa, 1998; A. KUPCZYK, Radykalne zmiany w firmie, PWE, Warszawa 1998; M. HAMMER, Reinżnieria $i$ jej następstwa. Jak organizacje skoncentrowane na procesach zmieniaja nasza pracę i nasze życie, $\mathrm{PWN}$, Warszawa, 1999.

9) PN-EN ISO 9000: 2001 System zarzadzania jakościa. Podstawy i terminologia, p. 3.2.14, s. 31.

10) Na podstawie A. MARKOWSKI (red.), Nowy stownik poprawnej polszczyzny PWN, Wydawnictwo Naukowe PWN, Warszawa 1999, s. 934.

11) Patrz m.in. R. MUNK, Project Management, Mc Hill, 2002, s. $35-46$.

12) Niniejsza mapa procesów ma postać tzw. drzewa funkcji; kolory związane są z zakresem systemu przedkładanym do certyfikacji.

13) Wymagania dotyczące dokumentacji System Zarządzania Jakością zostały określone w podstawowym zakresie w $\mathrm{p}$. 4.2.1., ISO 9001: 2000. W treści normy w sześciu jej punktach stawiany jest wymóg utrzymywania udokumentowanych procedur, np. ISO/ TS 16949: 2002 dodatkowo zobowiązuje do ustanowienia procedury szkoleń.

14) ISO 9000:2001, op.cit., p. 3.4.5, s. 35.

15) Por. E. KREIER, J. ŁUCZAK, ISO 9000 - tatwy i skuteczny sposób uzyskania certyfikatu zarzadzania jakościa, $\mathrm{Wy}-$ dawnictwo FORUM, Poznań, 1998-2004.

16) PDCA (plan - do - check - act)

17) Por. m.in. E. KREIER, J. ŁUCZAK, ISO 9000 - tatwy i skuteczny sposób uzyskania certyfikatu zarzadzania jakościa, Wydawnictwo FORUM 1998-2002; R.S. KAPLAN, D.P. NORTON, Strategiczna karta wyników. Jak przetozyć strategię na dziatanie, PWN, Warszawa 2001.

18) Zaprezentowany przykład został dla przejrzystości prezentacji w określony sposób przetworzony, przy czym w praktyce planowania, monitorowania i doskonalenia procesów konieczne jest rozszerzenie przedstawionego zestawienia o: właściciela wskaźnika (celu), termin realizacji, termin pomiaru, formę raportowania, wartość w poprzednim okresie, wartość bieżącą, status realizacji celu, uwagi.

19) Metoda Hoshin, określona także jako „zarządzanie przez Perseusza", umożliwia przede wszystkim formułowanie i osiąganie najistotniejszych celów organizacji przy zapewnieniu ich spójności i zbieżności działań różnych osób i komórek organizacyjnych. Patrz m.in. Z. MARTYNIAK, Hoshin-japońska metoda zarzadzania, „Organizacja i Kierowanie", nr 4 (94), 1998, s. 27-36.

20) M. HAMMER, J. CHAMPY, Reengineering in Corporation. A Manifesto for Business Revolution, HarperBusiness 1993, s. 49.

21) Por. E. KREIER, J. ŁUCZAK, ISO 9000 - tatwy i skuteczny sposób uzyskania certyfikatu zarzadzania jakościa, Wydawnictwo FORUM 1998-2002.

22) M. HAMMER, J. CHAMPY, Reengineering in Corporation. A Manifesto for Business Revolution, Harper Business 1993, s. 46. 